\title{
The role of triterpenes in the management of diabetes mellitus and its complications
}

\author{
J. Nazaruk • M. Borzym-Kluczyk
}

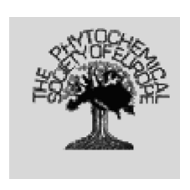

Received: 30 October 2013/Accepted: 13 June 2014/Published online: 24 June 2014

(C) The Author(s) 2014. This article is published with open access at Springerlink.com

\begin{abstract}
Diabetes mellitus is a chronic metabolic disease which is a serious global problem. In 2010 an estimated 285 million people had diabetes and within the next 20 years this value is expected to almost double. Many antidiabetic therapies focus on improving insulin sensitivity, increasing insulin production, and/or decreasing the level of blood glucose. Although a number of synthetic medicines are available, drugs of natural origin have aroused great interest. Triterpenes seem to demonstrate adequate properties. Many experiments have shown that these compounds have several antidiabetic mechanisms. They can inhibit enzymes involved in glucose metabolism, prevent the development of insulin resistance and normalize plasma glucose and insulin levels. These natural compounds, in contrast to synthetic drugs, apart from producing a hypoglycemic effect have also been found to manifest hypolipidemic and anti-obesity activity. Triterpenes are also promising agents in the prevention of diabetic complications. They have strong antioxidant activity and inhibit the formation of advanced glycation end products, implicated in the
\end{abstract}

J. Nazaruk $(\bowtie)$

Department of Pharmacognosy, Medical University of Białystok, Mickiewicza 2a Str., 15-089 Białystok, Poland e-mail: jolanta.nazaruk@umb.edu.pl

M. Borzym-Kluczyk

Department of Pharmaceutical Biochemistry, Medical University of Białystok, Mickiewicza 2a Str.,

15-089 Białystok, Poland pathogenesis of diabetic nephropathy, embryopathy, neuropathy or impaired wound healing. Until now very few clinical studies have been concerned with the application of triterpenes in treating diabetes. However, due to their great therapeutic potential, these compounds deserve special attention.

Keywords Diabetes mellitus · Triterpenes ·

Natural products

$\begin{array}{ll}\text { Abbreviations } \\ \text { AMPK } & \text { AMP-activated protein kinase } \\ \text { CHO/IR } & \begin{array}{l}\text { Chinese-hamster ovary cells expressing } \\ \text { human IR }\end{array} \\ \text { 2-DOG } & \left.\text { 2-Deoxy-D-[1- }{ }^{3} \mathrm{H}\right] \text { glucose } \\ \text { GLUT4 } & \text { Glucose transporter } \\ \text { HFD } & \text { High fat diet } \\ \text { IR } & \text { Insulin receptor } \\ \text { STZ } & \text { Streptozotocin }\end{array}$

\section{Introduction}

Triterpenes constitute a large structurally diverse group of natural compounds biogenetically derived from active isoprene. Two $\mathrm{C}_{15}$ units build squalene or related acyclic 30-carbon precursors. As the result of their cyclization and oxidation, various structures are 
Fig. 1 Chemical structures of the main subclasses of triterpenes

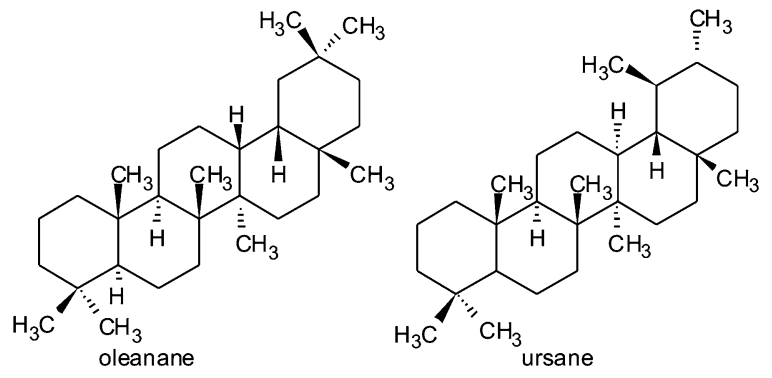

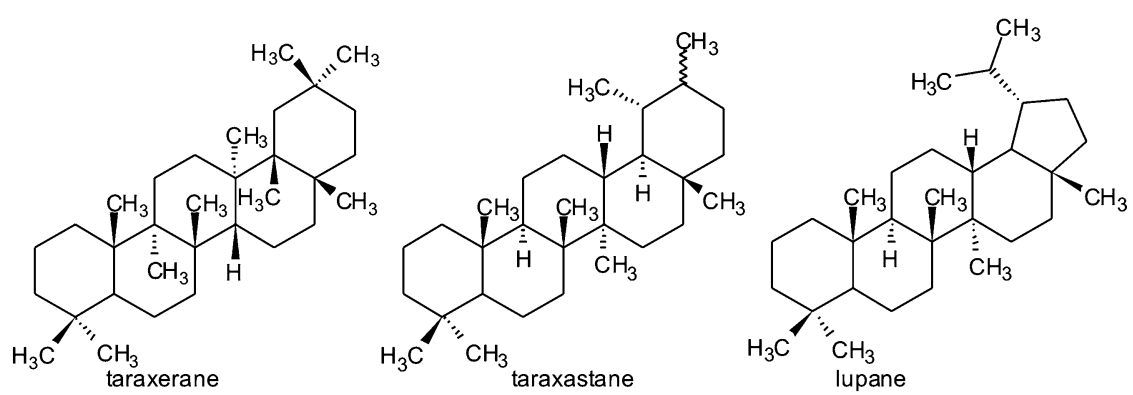

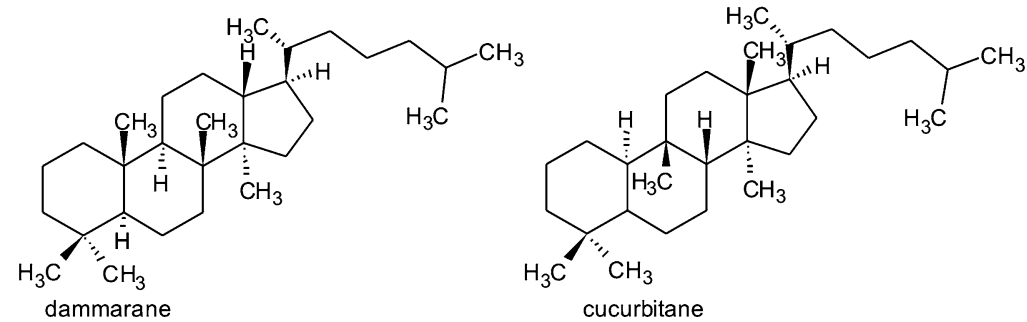

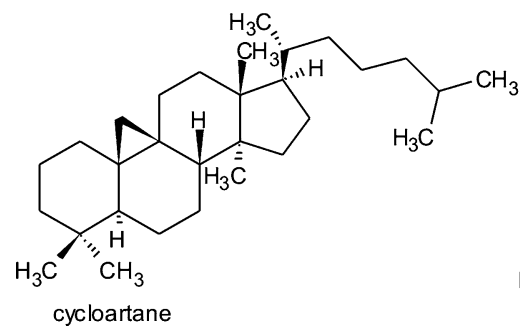

formed. Transformations occur in two ways, one producing tetra- and pentacyclic triterpenes and the other one leading through cycloartenole to cucurbitacines or to cholesterol and farther to phytosterols, cardiac glycosides and steroid saponins. The most common structures of triterpenes include pentacyclic-oleanane, ursane, taraxerane, taraxastane, lupane, and tetracyclic-dammarane and cucurbitane (Fig. 1) (Sticher 2010). Another group consists of nortriterpenoids formed from tetracyclic triterpene precursors through oxidation and degradation, resulting in fewer than thirty carbon atoms in the basic skeleton. These are divided into two groups: limonoids
$\left(\mathrm{C}_{26}\right)$ and quassinoids $\left(\mathrm{C}_{20}\right.$ and $\left.\mathrm{C}_{19}\right)$ (Harborne and Baxter 1993).

Triterpenes, especially pentacyclic ones, represent secondary metabolites that are widely distributed in the plant kingdom and found in leaves, stem bark, fruits and roots (Jäger et al. 2009). They are frequently the object of phytochemical and pharmacological investigations. The curative potential of triterpenes is very high yet still poorly recognized. Numerous in vitro and in vivo studies have revealed their multidirectional properties: anti-cancer (Laszczyk 2009), antioxidant (Ramachandran and Prasad 2008), anti-inflammatory (Yasukawa et al. 1996), anti- 
atherosclerotic (Sudhahar et al. 2007) or antiviral (Baltina et al. 2003).

Diabetes mellitus (DM) is a metabolic disease associated with disrupted insulin secretion or/and insulin action, resulting in high blood glucose levels. DM is primarily due to genetic or lifestyle factors, and creates a numerous therapeutic problems. Untreated diabetes can be the cause of many complications in retina, kidney or peripheral nerves and of macrovascular disturbances, such as ischemic heart disease and stroke (Ban and Twigg 2008). New drugs are still being sought to treat diabetic patients (Tahrani et al. 2011). Many natural triterpenoids seems to have promising antidiabetic properties. Their therapeutic possibilities and mechanisms of action are the subject of this review.

\section{Molecular target of triterpenes}

Triterpenes as $\alpha$-glucosidase and $\alpha$-amylase inhibitors

The therapeutic approach to treating type $2 \mathrm{DM}$ is to decrease postprandial glucose levels. It can be achieved through the inhibition of $\alpha$-glucosidases and $\alpha$-amylases which delay the absorbance of carbohydrates in the intestine, leading to a decrease in the postprandial insulin level (de Sales et al. 2012). There are many in vitro investigations indicating the ability of various plant-derived triterpenes to inhibit $\alpha$ glucosidase and $\alpha$-amylase activity.

2,3-seco-20(29)-Lupene-2,3-dioic acid, obtained from leaves and twigs of Fagus hayatae (Fagaceae), showed inhibitory activity against $\alpha$-glucosidase type IV (from Bacillus stearothermophilus), with $\mathrm{IC}_{50}$ equaling $62.1 \mu \mathrm{M}$ (the positive control acarbose $\mathrm{IC}_{50}$ $23 \mathrm{nM}$ ) (Lai et al. 2012). Compounds isolated from the root bark of Euclea undulate (Ebenaceae), namely $\alpha$ amyrin-3O- $\beta$-(5-hydroxy) ferulic acid- $\mathrm{IC}_{50} 7.76 \mu \mathrm{M}$ correlating with those of the positive control, acarbose $\left(\mathrm{IC}_{50} 7.35 \mu \mathrm{M}\right.$ ) and lupane- $\mathrm{IC}_{50} 14.69 \mu \mathrm{M}$, have been found to inhibit $\alpha$-glucosidase type 1 from baker's yeast (Deutschländera et al. 2011). Corosolic acid (1-hydroxyursolic acid) isolated from the leaves of Lagerstroemia speciosa (Lythraceae) shows bioactivity against $\alpha$-glucosidase from yeast with $\mathrm{IC}_{50}$ $3.53 \mu \mathrm{g} / \mathrm{mL}$, (acarbose $\mathrm{IC}_{50} \quad 1.82 \mu \mathrm{g} / \mathrm{mL}$ ). The remaining constituents of this plant-maslinic acid, oleanolic acid and 23-hydroxyursolic acid exhibit a lower activity where their $\mathrm{IC}_{50}$ equaled 5.52, 6.29 and $8.14 \mu \mathrm{g} / \mathrm{mL}$, respectively. The research of kinetics showed that these triterpene acids inhibited the enzyme uncompetitively (Hou et al. 2009). Pistagremic acid, dammarane type triterpene obtained from galls of Pistacia chinensis var. integerrima (Anacardiaceae), shows potent enzyme inhibitory activity both against yeast $\left(\mathrm{IC}_{50} 89.12 \mu \mathrm{M}\right.$, acarbose $\mathrm{IC}_{50}$ $780.21 \mu \mathrm{M})$ and rat intestinal $\left(\mathrm{IC}_{50} 62.47 \mu \mathrm{M}\right.$, acarbose $\mathrm{IC}_{50} 38.92 \mu \mathrm{M}$ ) $\alpha$-glucosidases (Uddin et al. 2012). The binding mode of pistagremic acid to the $\alpha$ glucosidase was analyzed using molecular docking simulations. It has a proper molecular shape and size for forming hydrogen bonds with an important amino acid surrounding the catalytic site of this enzyme (Uddin et al. 2012). Several ursane and oleane type triterpenes isolated from the roots of Sanguisorba tenuifolia (Rosaceae) have been found to exhibit dosedependent $\alpha$-glucosidase inhibitory activity and their $\mathrm{IC}_{50}$ value ranged between 0.62 and $3.62 \mathrm{mM}$. The most active inhibitors of the enzyme were euscaphic acid and $p$-coumaroylursolic acid whose $\mathrm{IC}_{50}$ values were 0.67 and $0.62 \mathrm{mM}$, respectively, comparable with acarbose having an $\mathrm{IC}_{50}$ value of $0.79 \mathrm{mM}$ (Kuang et al. 2011). Oleanolic and ursolic acids found in Phyllanthus amarus (Euphorbiaceae) inhibited porcine pancreatic $\alpha$-amylase. The $\mathrm{IC}_{50}$ value for the mixture of these compounds in the $2: 1$ ratio was $4.41 \mu \mathrm{M}$, however the second compound was much more active than the first one (Ali et al. 2006). Oleanane-type triterpene bartogenic acid, isolated from seeds of Barringtonia racemosa (Lecythidaceae), demonstrated moderate inhibitory activity against both enzymes ( $\alpha$-amylase type VIB from porcine pancreas and $\alpha$-glucosidase type I from baker's yeast and intestinal enzyme). The $\mathrm{IC}_{50}$ value of bartogenic acid for the latter enzyme was $168.09 \mu \mathrm{g} / \mathrm{mL}$ (Gowri et al. 2007).

The influence of triterpenes on aldose reductase

Under normoglycemia most cellular glucose is phosphorylated into glucose 6-phosphate by hexokinase. A minor part of nonphosphorylated glucose enters the alternate route of the glucose metabolism, the so-called polyol pathway. In the first step of this pathway aldose reductase catalyzes the reduction of glucose into sorbitol. In the second step sorbitol is subsequently 
converted to fructose by sorbitol dehydrogenase (Cheng and González 1986). Under normoglycemic conditions aldose reductase might function physiologically as a general housekeeping enzyme, but under hyperglycemia, when the metabolism of glucose through the polyol pathway is significantly increased, it leads to diabetic microvascular complications (Petrash 2004).

This process can be inhibited by some triterpene compounds (Fig. 2). Aldose reductase inhibitors were found among friedelane derivatives (kotalagenin 16 -acetate) and isomeric oleanane derivatives (maytenfolic acid and 3 $\beta, 22 \alpha$-dihydroxyolean-12-en-29oic acid), obtained from the roots of Salacia oblonga (Celastraceae). When they were used at a concentration of $100 \mu \mathrm{M}$ the percentage of enzyme inhibition was $48.2,54.6$ and $75.9 \%$, respectively (Matsuda et al. 1999).

Triterpenoids as protein tyrosine phosphatase 1B (PTP 1B) inhibitors

Protein tyrosine phosphatases are enzymes which regulate cellular signaling and metabolism (Thareja et al. 2012). PTPases have been divided into two broad types, intracellular and transmembrane. PTP 1B belongs to a group of intracellular enzymes which cause negative regulation of insulin receptors as well as of the leptin signaling system. They are responsible for dephosphorylation process of the receptor $\beta$-subunit (Goldstein 2002). Inhibitors of PTP 1B can potentially ameliorate insulin resistance and normalize plasma glucose and insulin levels without inducing hypoglycemia (Thareja et al. 2012). Triterpenes with PTP 1B inhibitory activity are presented in Table 1 and their molecular target is demonstrated in Fig. 3.

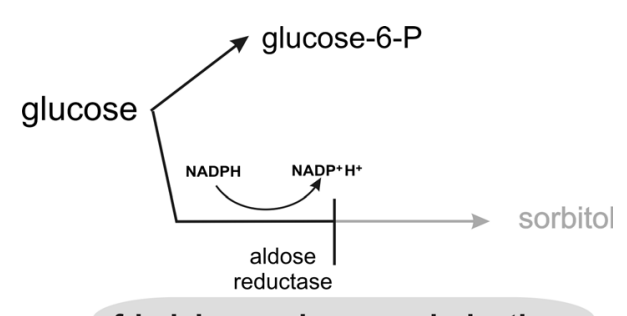

friedelane, oleanane derivatives

Fig. 2 Inhibitory effect of triterpenes on sorbitol pathway
Some of the natural compounds examined were more active or had activity similar to RK-682 ( IC $_{50}$ $4.5 \mu \mathrm{M})$, which was used almost in all experiments as a positive control. Among the reviewed derivatives ursolic acid seemed to be the most active. This is important because it is a widely occuring pentacyclic triterpene (Sticher 2010).

The structure of the triterpenes plays a key role in inhibition of PTP 1B. As reported by Na et al. (2006a) and Kwon et al. (2008) the hydroxyl group at C-3 and the carboxyl group at C-28 or C-27 of the oleanane-type triterpenes are essential structural elements related to inhibitory activity. Similar to triterpenes isolated from leaves of Rhododendron brachycarpum, the hydroxyl group at $\mathrm{C}-3$ in the ursane-type also seems indispensable for enzyme inhibition and the C-28 carboxyl group can form hydrogen bonds at the PTP $1 \mathrm{~B}$ catalytic binding site (Choi et al. 2012). The inhibitory potency appears to become stronger when the lipophilicity of the tested compounds was increased (Choi et al. 2012). The main mode of action of triterpene acids isolated from leaves and stems of Phoradendron reichenbachianum was through PTP 1B enzymatic inhibition with the potent, reversible, selective and linear mixed-type inhibition models, and it is worth to noticing, that at a concentration of $50 \mu \mathrm{M}$ enzyme activity was almost completely stopped (Ramírez-Espinosa et al. 2011). All compounds also showed moderate or weak activity toward other structurally related PTPases, such as the IF1, IF2 isoenzymes of human LMW-PTP, yeast LMW-PTP (LTP1) and human LAR (Ramírez-Espinosa et al. 2011). Ursolic acid, apart from PTP 1B, displayed obvious selectivity for other nonreceptor-type PTPs-TCPTP (T cell protein tyrosine phosphatase) and SHP2 (src homology phosphatase-2), with $\mathrm{IC}_{50}$ levels of 3.33 and $2.73 \mu \mathrm{M}$, respectively (Zhang et al. 2006). TCPTP, SHP1 (src homology phosphatase-1) and SHP2 were also inhibited by corosolic acid, with their $\mathrm{IC}_{50}$ levels equaling 11.31, 24.56 and $10.50 \mu \mathrm{M}$, respectively (Shi et al. 2008).

Ilekudinol A and B isolated from W. subsessilis inhibited PTP1B in a non-competitive manner. This observation seems to indicate that a free carboxyl group at C-28 of 24-norursane triterpenes is essential to the inhibitory activity towards PTP $1 \mathrm{~B}(\mathrm{Na}$ et al. 2010). Lupane type triterpenes isolated from the stem bark of Sorbus commixta also inhibited PTP $1 \mathrm{~B}$ in a non-competitive manner ( $\mathrm{Na}$ et al. 2009). 
Table 1 Triterpenoid inhibitors of PTP 1B

\begin{tabular}{|c|c|c|c|}
\hline Compound & $\begin{array}{l}\mathrm{IC}_{50} \\
(\mu \mathrm{M})\end{array}$ & Plant (family) & References \\
\hline 3-Oxoolean-12-en-27-oic acid & 6.8 & Astilbe koreana (Saxifragaceae) & $\mathrm{Na}$ et al. (2006a) \\
\hline $3 \beta$-Hydroxyolean-12-en-27-oic acid & 5.2 & & \\
\hline $3 \beta$-Hydroxyurs-12-en-27-oic acid & 4.9 & & \\
\hline $3 \alpha, 24$-Dihydroxyolean-12-en-27-oic acid & 11.7 & & \\
\hline $3 \beta, 6 \beta$-Dihydroxyolean-12-en-27-oic acid & 12.8 & & \\
\hline \multirow[t]{3}{*}{ Oleanolic acid } & 3.9 & - & \\
\hline & 9.5 & $\begin{array}{l}\text { Phoradendron reichenbachianum } \\
\text { (Viscaceae) }\end{array}$ & $\begin{array}{l}\text { Ramírez-Espinosa et al. } \\
\text { (2011) }\end{array}$ \\
\hline & 14.4 & Sambucus adnata (Caprifoliaceae) & Sasaki et al. (2011) \\
\hline $3 \beta$-Hydroxyolean-12-en-28-oic acid & 5.2 & Styrax japonica (Styracaceae) & Kwon et al. (2008) \\
\hline $3 \beta$-Acetoxyolean-12-en-28-acid & 7.8 & & \\
\hline $3 \beta$-Acetoxyolean-12-en-28-aldehyde & 9.3 & & \\
\hline \multirow[t]{5}{*}{ Ursolic acid } & 2.3 & $\begin{array}{l}\text { Phoradendron reichenbachianum } \\
\text { (Viscaceae) }\end{array}$ & $\begin{array}{l}\text { Ramírez-Espinosa et al. } \\
\text { (2011) }\end{array}$ \\
\hline & 3.08 & Cornus officinalis (Cornaceae) & Zhang et al. (2006) \\
\hline & 3.8 & $\begin{array}{l}\text { Symplocos paniculata } \\
\quad \text { (Symplocaceae) }\end{array}$ & Na et al. (2006b) \\
\hline & 4.1 & Sambucus adnata (Caprifoliaceae) & Sasaki et al. (2011) \\
\hline & 3.1 & $\begin{array}{l}\text { Rhododendron brachycarpum } \\
\text { (Ericaceae) }\end{array}$ & Choi et al. (2012) \\
\hline Moronic acid & 13.2 & $\begin{array}{l}\text { Phoradendron reichenbachianum } \\
\text { (Viscaceae) }\end{array}$ & $\begin{array}{l}\text { Ramírez-Espinosa et al. } \\
\text { (2011) }\end{array}$ \\
\hline Morolic acid & 9.1 & & \\
\hline \multirow[t]{2}{*}{ Corosolic acid } & 7.2 & $\begin{array}{l}\text { Symplocos paniculata } \\
\text { (Symplocaceae) }\end{array}$ & $\mathrm{Na}$ et al. (2006b) \\
\hline & 7.0 & $\begin{array}{l}\text { Rhododendron brachycarpum } \\
\text { (Ericaceae) }\end{array}$ & Choi et al. (2012) \\
\hline $\begin{array}{l}2 \alpha, 3 \beta \text {-Dihydroxy-24-nor-urs-4(23),11-dien-28,13 } \beta \text {-olide } \\
\text { (ilekudinol A) }\end{array}$ & 29.1 & $\begin{array}{l}\text { Weigela subsessilis } \\
\quad \text { (Caprifoliaceae) }\end{array}$ & Na et al. (2010) \\
\hline $\begin{array}{l}\text { 2 } \alpha, 3 \beta \text {-Dihydroxy-24-nor-urs-4(23),12-dien-28-oic acid } \\
\text { (ilekudinol B) }\end{array}$ & 5.3 & & \\
\hline Rhododendric acid & 6.3 & $\begin{array}{l}\text { Rhododendron brachycarpum } \\
\text { (Ericaceae) }\end{array}$ & Choi et al. (2012) \\
\hline (20S)-Dammarane-24(25)-ene-3 $\beta, 20,21$-tetrol & 15.2 & $\begin{array}{l}\text { Gynostemma pentaphyllum } \\
\text { (Cucurbitaceae) }\end{array}$ & Zhang et al. (2013) \\
\hline $\begin{array}{l}(20 R, 23 R)-3 \beta, 20-D i h y d r o x y l d a m m a r a n e-24-e n e-21-o i c \\
\text { acid-21,23-lactone }\end{array}$ & 8.4 & & \\
\hline $3 \beta$-Hydroxyetio- $17 \beta$-dammaranic acid & 13.1 & & \\
\hline Lupeol & 5.6 & Sorbus commixta (Rosaceae) & Na et al. (2009) \\
\hline Lupenone & 13.7 & & \\
\hline Hopane-6 $\alpha, 22$-diol & 3.7 & $\begin{array}{l}\text { Lecidella carpathica } \\
\text { (Lecanoraceae) }\end{array}$ & Seo et al. (2011) \\
\hline Brialmontin 1 & 14.0 & & \\
\hline
\end{tabular}




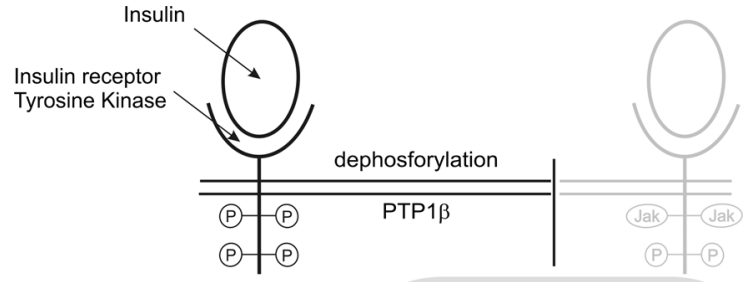

3-OH triterpenic acids

Fig. 3 Triterpenes as PTP 1B inhibitors

The influence of triterpenoids on glycolytic and related enzymes

Among glycolytic enzymes, glyceraldehyde-3-phosphate dehydrogenase (GAPDH), a key enzyme in glycolysis, plays a role in membrane fusion, phosphotransferase activity and apoptosis, whereas glycerol-3phosphate dehydrogenase (G3PDH) catalyzes the reversible biological reduction in glycerone phosphate using NADH as a reducing equivalent to form glycerol-3-phosphate (Ishijima et al. 2008).

The influence on these enzymes has been described for gymnemic acid, which is the mixture of approximately 10 oleanane-type tritepene saponins, found in leaves of Gymnema sylvestre (Asclepiadaceae). This mixture inhibited rabbit GAPDH and induced dephosphorylation of G3PDH and GAPDH (Fig. 4). It may have some physiological effects on glucose, glycerol and lipid metabolisms (Ishijima et al. 2008).

Glycogen phosphorylase inhibitors

The level of glucose is regulated by hepatic glicogen phosphorylase (GP) catalyzing glycogenolysis resulting in an increased hepatic glucose output and glycogen synthase, which stimulates gluconeogenesis (Tahrani et al. 2011). GP exists in two interconvertible forms: dephosphorylated low-activity form, GPb, and phosphorylated high-activity form, GPa. In both forms, allosteric effectors can promote equilibrium between the less active $\mathrm{T}$ state and the more active $\mathrm{R}$ state (Oikonomakos et al. 2000). This enzyme is inhibited by insulin and activated by glucagon and other counter-regulatory hormones (Tahrani et al. 2011). It has been stated that in diabetes activity of GT is increased, therefore inhibitors of glycogen phosphorylase have been studied as potential therapy for attenuating hyperglycemia associated with type 2 diabetes (Baker et al. 2005).

Among triterpenes most reports concern oleanane derivatives as potential GP inhibitors. Several such compounds were isolated from the roots of Gypsophila oldhamiana (Caryophyllaceae), with oleanolic acid and hederagenin being the most active GP inhibitors. At a concentration of $10 \mu \mathrm{M}$ both compounds showed $73.07 \%$ of GP inhibition, as compared to a similar compound, gypsogenin, with $45.11 \%$ inhibition, whereas the positive control (caffeine in the concentration of $15 \mu \mathrm{M}$ ) showed $50 \%$ inhibition of this enzyme (Luo et al. 2008). The authors, after comparing this with other compounds, suggest that the activity depends on the presence of a hydroxyl group at $\mathrm{C}-3$ and $\mathrm{CH}_{3}$ or $\mathrm{CH}_{2} \mathrm{OH}$ groups at $\mathrm{C}-23$ in the oleanane skeleton (Luo et al. 2008). Tormentic acid and asiatic acid obtained from the whole plant of Potentilla biscolor (Rosaceae) showed moderate $\left(\mathrm{IC}_{50}\right.$ $90.5 \mu \mathrm{M}, 65.4 \mu \mathrm{M}$, respectively), but higher than caffeine ( $\mathrm{IC}_{50} 158 \mu \mathrm{M}$ ) inhibition of GP (Yang et al. 2010). On the other hand corosolic acid and maslinic acid were much more potent as liver GP inhibitors ( $\mathrm{IC}_{50} 101$ and $99 \mu \mathrm{M}$, respectively) than the positive control (caffeine, $\mathrm{IC}_{50} 648 \mu \mathrm{M}$ ) (Wen et al. 2005). The action of triterpenes on these enzymes is presented in Fig. 5.
Fig. 4 The influence of gymnemic acid on glycerol metabolism

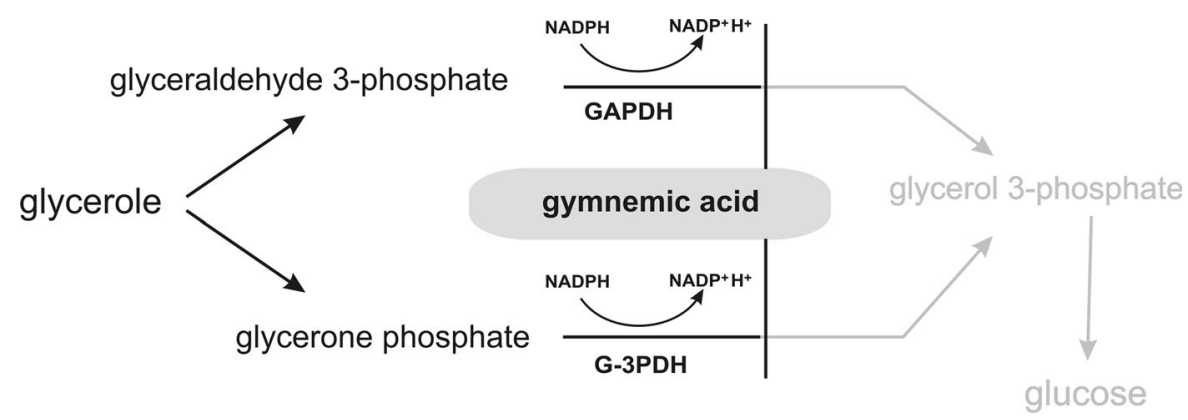


The influence of triterpenes on $11 \beta$-hydroxysteroid dehydrogenase type 1 (11 $\beta$-HSD1)

$11 \beta$-Hydroxysteroid dehydrogenase type I $(11 \beta$ HSD1) is the enzyme that converts inactive 11-ketoglucocorticoids into active $11 \beta$-hydroxyforms in metabolically relevant tissues such as the liver, adipose tissue, skeletal muscles and pancreatic $\beta$-cells. Type II of this enzyme converts active cortisol into inactive cortisone, thereby preventing inappropriate mineralocorticoid receptor activation by glucocorticoids in aldosterone target tissues such as kidney, colon and salivary glands. Non-selective inhibition of $11 \beta$-HSD results in serious side-effects such as sodium retention, hypokalaemia and hypertension (Lipson et al. 2011). Chronically elevated local glucocorticoid action as a result of increased $11 \beta$-HSD1 activity is associated with metabolic syndrome, obesity, insulin resistance, type 2 diabetes mellitus and cardiovascular complications (Wamil and Seckl 2007). Selective inhibition of $11 \beta$-HSD1 has been proposed as a strategy to suppress glucocorticoid action in tissue specific manner. Many studies suggest that inhibition or down-regulation of $11 \beta$-HSD1 provides a decrease of excessive hepatic glucose production in hyperglycemia and diabetes mellitus, and exerts a positive effect on insulin sensitivity in diabetic subjects (Alberts et al. 2002; Stulnig and Waldhäusl 2004; Atanasov et al. 2006).

The ability to selectively inhibit11 $\beta$-HSD1 (Fig. 6) has been demonstrated for many semisynthetic (nanomolar value of $\mathrm{IC}_{50}$ ) and natural ursane and oleanane derivatives (Blum et al. 2009). Strong activity has

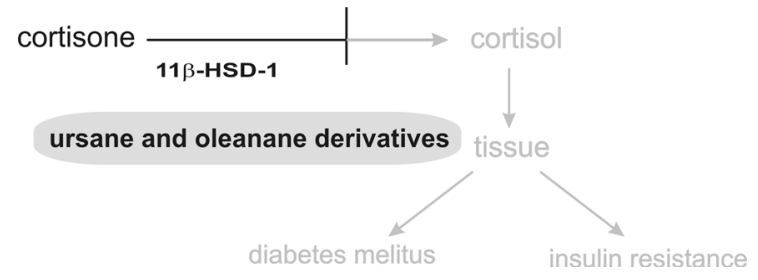

Fig. 6 The role of triterpenes in cortisone metabolism

been exhibited by ursolic acid, 3-epicorosolic acid methyl ester, tormentic acid methyl ester and 2- $\alpha$ hydroxy-3-oxours-12-en-28-oic acid ( IC $_{50} 1.9$, 5.2, 9.4 and $17 \mu \mathrm{M}$, respectively) isolated from leaves of Eriobotrya japonica (Rosaceae) (Rollinger et al. 2010). Interestingly the mixture of these compounds showed a significantly increased inhibitory potential on $11 \beta$-HSD1. An important role in ligand binding to the enzyme can be ascribed to carboxylic groups at C-17 and C-23, hydroxyl groups at C-2 and C-3, with the $2 S, 3 R$ configuration seeming to be optimal (Rollinger et al. 2010). Constituents of Bursera delpechiana 11-keto-ursolic acid and 3-acetyl-11-keto-ursolic acid have also been reported as selective inhibitors of $11 \beta$-HSD1. Their $\mathrm{IC}_{50}$ values are equal to 2.06 and $1.35 \mu \mathrm{M}$, respectively (Rollinger et al. 2010).

The influence of triterpenes on the TGR5 receptor and its implication in diabetes

TGR5, an emerging G protein-coupled receptor, was identified as a membrane receptor for bile acids. The expression of TGR5 and its function are distinct from
Fig. 5 The action of triterpenes on glycogen phosphorylase

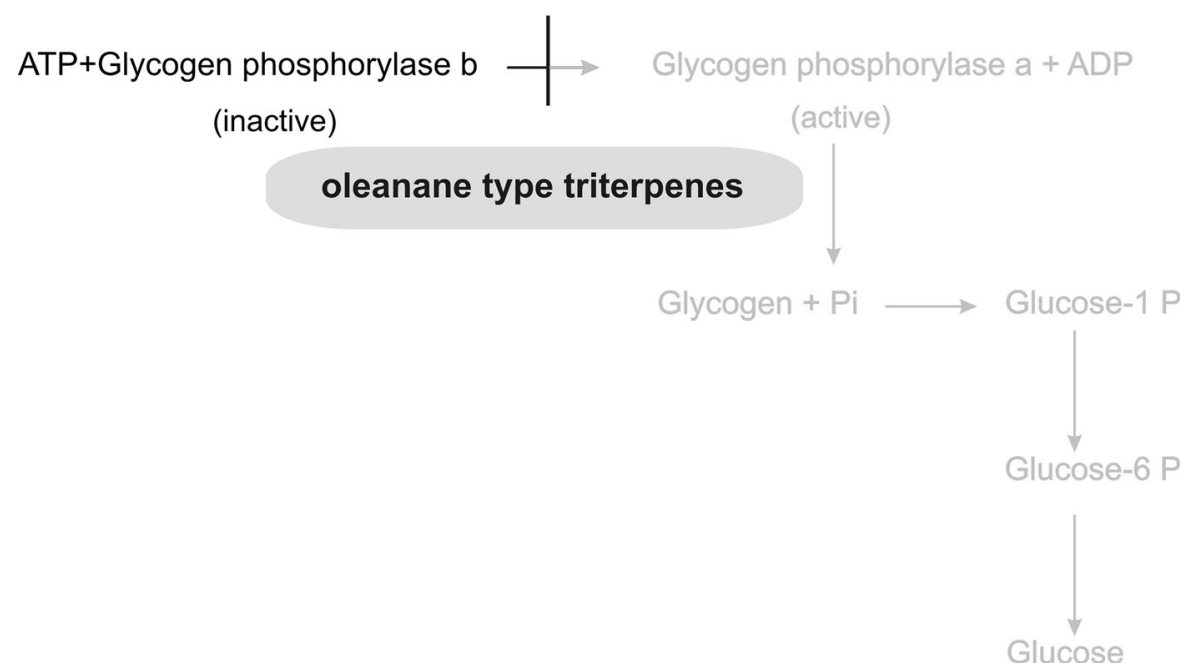


the previously identified nuclear bile acid receptor, the farnesoid $\mathrm{X}$ receptor (FXR). These two bile acid receptors complement each other in maintaining bile acid homeostasis and mediating bile acid signaling. Both receptors also play roles in regulating inflammation and glucose metabolism (Chen et al. 2011). An interesting finding for TGR5 is its role in energy metabolism. The discovery of TGR5 expression in brown adipocyte tissues (BATs) and the recent discovery of BAT in the adult human body suggest a potential approach to combat obesity by targeting TGR5 to increase thermogenesis. The agonists of this receptor can also be used for the prevention of the development of insulin resistance in early stages of diabetes mellitus (Chen et al. 2011).

Oleanolic acid, a selective TGR5 agonist, which does not influence FXR is isolated from the leaves of Olea europaea (Oleaceae) (Sato et al. 2007). Other compounds with agonistic properties include betulinic acid and ursolic acid (Genet et al. 2010a). Betulinic acid is the most active (83\% efficacy with respect to litocholic acid used as positive control) of these three triterpenes mentioned above. The values of $\mathrm{EC}_{50}$ for oleanolic, betulinic and ursolic acids were 2.25; 1.04; $1.43 \mu \mathrm{M}$, respectively (Genet et al. 2010a). A comparison with other compounds having similar structure has proven that the hydroxyl group at C-3 plays a role in this type of activity. Unfortunately oleanolic acid has weak metabolic stability when administrated orally to rats and very low bioavailability (Sato et al. 2007; Genet et al. 2010a, b).

Nomilin, a highly oxygenated limonoid-type triterpene specific for Citrus sp., has also been recognized as an activator of TGR5. Its influence on TGR5 was higher than the natural agonist, chenodeoxycholic acid. Similar to the compounds mentioned above it does not induce FXR activity. Experimental animals treated with nomilin $(0.2 \%)$ had a lower body weight, decreased serum glucose and serum insulin, and an enhanced glucose tolerance (Ono et al. 2011).

\section{Tests on the antidiabetic activity of triterpenes}

Experiments on the antidiabetic potential of natural products are carried out mainly in vivo, and are often complemented with in vitro studies to explore the mechanism of action of extracts or isolated compounds. Among animal models of DM those with pharmacologically induced diabetes and surgical or genetic models of diabetes are used. In vitro studies concern mainly insulin secretion and glucose uptake (Fröde and Medeiros 2008).

Many crude extracts of plants and isolated triterpenoids have been tested with regard to their antidiabetic and antihyperglycemic activity. Table 2 presents various cell models and Table 3 shows animal models adapted to test the antidiabetic activity of triterpenes.

The result of this review demonstrate that triterpenes often exert an effect on insulin biosynthesis, secretion and signaling. Additionally they also prevent pancreatic $\beta$-cell function, regulate total cholesterol and triglicerides level and body weight.

\section{Terpenoid sweetness inhibitors}

It has been observed that subjects whose perception of sweetness had been decreased reduced consumption of total calories and sweet calories. This could be important in the prevention of uncontrolled glucose level elevation (Brala and Hagen 1983).

Sweetness inhibitors of terpenoid origin have been identified in some plants. These compounds were initially isolated from the leaves of Gymnema sylvestre and include oleanane-type saponins: gymnemic acid I-VI, X-XVIII and gymnema saponins. Unlike glycosides their aglycones are inactive. Such compounds, including ziziphin, jujubasaponins II-VI and dammarane type saponins are found in Ziziphus jujuba (Rhamnaceae). Dammarane derivatives, such as hodulcin, hodulosides I-IX and jujuboside B can be isolated from Hovenia dulcis (Rhamnaceae). Interestingly, the time for the recovery of the ability to taste sweetness differs for compounds from every plant. For G. sylvestre it is $15 \mathrm{~min}-24 \mathrm{~h}$, for $Z$. jujube it is 5-10 min and for H. dulcis it is 1-4 min (Suttisri et al. 1995).

\section{Reduction of diabetes mellitus complications}

Antioxidants in diabetes mellitus

It has been shown in various studies that diabetes mellitus is associated with the increased formation of free radicals and a decrease in antioxidant potential (Rahimi et al. 2005). Oxidative stress induced by 
Table 2 In vitro studies on antidiabetic activity of triterpenes

\begin{tabular}{|c|c|c|c|c|}
\hline Plant (family) & Compound & Model & Result & References \\
\hline $\begin{array}{l}\text { Momordica } \\
\text { charantia } \\
\text { (Cucurbitaceae) }\end{array}$ & $\begin{array}{l}\text { Karaviloside XI } \\
\text { Momordicoside S } \\
\text { 19-Epoxycucurbita-6-ene- } \\
\text { 23(R),24(S),25-triol } \\
\text { 3-O- } \beta \text {-D-Glucopyranosyl } \\
\text { 22( } S), 23(R), 24(R), \\
\text { 25-tetrahydroxycucurbit- } \\
\text { 5-ene } \\
\text { Momordicine II } \\
\text { Kuguaglycoside G }\end{array}$ & $\begin{array}{l}\text { L6 muscle } \\
\text { cells, 3T3L1 } \\
\text { adipocytes } \\
\text { MIN6 } \beta \text {-cells }\end{array}$ & $\begin{array}{l}\uparrow \text { GLUT4 translocation } \\
\uparrow \text { AMPK } \\
\uparrow \text { Insulin secretion }\end{array}$ & $\begin{array}{l}\text { Tan et al. } \\
(2008) \\
\text { Keller } \\
\text { et al. } \\
(2011)\end{array}$ \\
\hline $\begin{array}{l}\text { Poria cocos } \\
\qquad \text { (Polyporaceae) }\end{array}$ & Pachymic acid & $\begin{array}{l}\text { 3T3-L1 } \\
\text { adipocytes }\end{array}$ & $\begin{array}{l}\uparrow \text { GLUT4 } \\
\uparrow \text { Phosphorylation of insulin receptor substrate } \\
\text { (IRS)-1 } \\
\uparrow \text { Akt and AMPK }\end{array}$ & $\begin{array}{l}\text { Huang } \\
\text { et al. } \\
\text { (2010) }\end{array}$ \\
\hline $\begin{array}{c}\text { Panax ginseng } \\
\text { (Araliaceae) }\end{array}$ & Ginsenoside Rc & $\begin{array}{l}\mathrm{C} 2 \mathrm{C} 12 \\
\text { myotubes }\end{array}$ & $\begin{array}{l}\uparrow \text { Glucose uptake via activation of p38MAPK } \\
\text { and AMPK thanks intracellular ROS } \\
\text { generation }\end{array}$ & $\begin{array}{l}\text { Lee et al. } \\
\text { (2010) }\end{array}$ \\
\hline $\begin{array}{l}\text { Campsis } \\
\text { grandiflora } \\
\text { (Bignoniaceae) }\end{array}$ & Ursolic acid & $\begin{array}{l}\text { CHO/IR cells } \\
\text { 3T3-L1 } \\
\text { adipocytes }\end{array}$ & $\begin{array}{l}\uparrow \operatorname{IR} \beta \text { auto-phosphorylation tyrosine } \\
\uparrow \text { Phosphorylation of the IR } \beta \text {-subunit, } \\
\text { phosphorylation of Akt and glycogen synthase } \\
\text { kinase- } 3 \beta \\
\uparrow \text { Insulin-stimulated GLUT4 translocation }\end{array}$ & $\begin{array}{c}\text { Jung et al. } \\
\text { (2007) }\end{array}$ \\
\hline $\begin{array}{l}\text { Celastrus } \\
\text { vulcanicola } \\
\text { (Celastraceae) }\end{array}$ & $\begin{array}{l}7 \beta \text {-Hydroxy-3-oxo-D:A- } \\
\text { friedooleanan-28-oic } \\
\text { acid (1) } \\
\text { 7 } \beta, 29 \text {-Dihydroxy-3-oxo- } \\
\text { D:A-friedooleanane (2) }\end{array}$ & $\begin{array}{l}\text { Huh7 cells } \\
\text { (human } \\
\text { hepatic cells) }\end{array}$ & $\begin{array}{l}\uparrow \text { Phosphorylation of IR (in the absence of } \\
\text { insulin } \\
\uparrow \text { Insulin-mediated IR tyrosine phosphorylation } \\
\text { (only 1) }\end{array}$ & $\begin{array}{l}\text { Ardiles } \\
\text { et al. } \\
\text { (2012) }\end{array}$ \\
\hline- & Astragaloside IV & $\begin{array}{l}\text { 3T3-L1 } \\
\text { adipocytes }\end{array}$ & $\begin{array}{l}\uparrow \text { Insulin stimulated } \\
\text { 2-DOG uptake, antagonized the TNF } \alpha \text {-induced } \\
\text { insulin resistance }\end{array}$ & $\begin{array}{l}\text { Jiang et al. } \\
\text { (2008) }\end{array}$ \\
\hline
\end{tabular}

hyperglycemia and free fatty acids causes insulin resistance, $\beta$-cell dysfunction, and late diabetic complications (Evans et al. 2002; Manna et al. 2009). Figure 7 shows disorders triggered by oxidative stress in kidney and serum.

The application of antioxidants especially of natural origin is one of the strategies in treating DM (Rahimi et al. 2005). Triterpenes play an important role as plant antioxidants. Ursolic acid exhibited hydroxyl radical scavenging activity, perhaps through its hydrogen donating ability. It also scavenged superoxide anions (Ramachandran and Prasad 2008). Corosolic acid reduced levels of thiobarbituric acidreactive substance (TBARS) and 8-hydroxydeoxyguanosine (8-OHdG), both of which are oxidative stress biomarkers (Yamaguchi et al. 2006). Arjunoic acid present in the bark of Terminalia arjuna showed considerable activity against oxidative processes. This oleanane derivative prevented alternation of STZinduced intracellular RNS and ROS formation in spleen tissue, deactivated the polyol pathway, enhanced the level of IL-2 and IFN- $\gamma$ and decreased the level of TNF- $\alpha$ (Manna et al. 2010). The lupanetype triterpene, bacosine, obtained from the herb of Bacopa monnieri (Scrophulariaceae) also displayed antioxidant properties. This compound significantly decreased the level of malonylaldehyde, increased the level of glutathione (GSH) and the activity of superoxide dismutase (SOD) and catalase (CAT) in the liver of diabetic rats (Ghosh et al. 2011). 
Table 3 Antidiabetic activity of triterpenes tested in animal models

\begin{tabular}{|c|c|c|c|c|}
\hline Plant (family) & Compound & Model & Result & References \\
\hline $\begin{array}{l}\text { Momordica } \\
\text { charantia } \\
\text { (Cucurbitaceae) }\end{array}$ & $\begin{array}{l}\text { Momordicoside } \mathrm{S} \\
\text { momordicoside } \mathrm{T}\end{array}$ & $\begin{array}{l}\text { Insulin-sensitive } \\
\text { and insulin- } \\
\text { resistant mice }\end{array}$ & $\begin{array}{l}\uparrow \text { Glucose tolerance } \\
\uparrow \text { Fatty acid oxidation }\end{array}$ & $\begin{array}{c}\text { Tan et al. } \\
\text { (2008) }\end{array}$ \\
\hline $\begin{array}{l}\text { Eriobotrya } \\
\text { japonica } \\
\text { (Rosaceae) }\end{array}$ & $\begin{array}{l}\text { Extract containing above } 50 \% \text { of } \\
\text { triterpene acids (tormentic, } \\
\text { corosolic, maslinic, oleanolic and } \\
\text { ursolic acid) }\end{array}$ & $\begin{array}{l}\text { Alloxan- and STZ- } \\
\text { diabetic mice, } \\
\text { HFD mice }\end{array}$ & $\begin{array}{l}\uparrow \text { Serum insulin level } \\
\uparrow \text { SOD } \\
\downarrow \text { Glycosylated serum protein } \\
\downarrow \text { Total cholesterol and } \\
\text { triglyceride reversing of insulin } \\
\text { resistance }\end{array}$ & $\begin{array}{l}\text { Lü et al. } \\
\text { (2009), } \\
\text { Shih et al. } \\
\text { (2010) }\end{array}$ \\
\hline $\begin{array}{l}\text { Poria cocos } \\
\text { (Polyporaceae) }\end{array}$ & $\begin{array}{l}\text { Lanostane-type terpenoids: } \\
\text { dehydrotumulosic acid, } \\
\text { dehydrotrametenolic acid, pachymic } \\
\text { acid }\end{array}$ & $\begin{array}{l}\text { Diadetic db/db } \\
\text { STZ-treated } \\
\text { mice }\end{array}$ & $\begin{array}{l}\downarrow \text { Postprandial blood glucose } \\
\text { level } \\
\uparrow \text { Insulin sensitivity }\end{array}$ & $\begin{array}{l}\text { Sato et al. } \\
\text { (2002), Li } \\
\text { et al. } \\
\text { (2011) }\end{array}$ \\
\hline $\begin{array}{l}\text { Protium } \\
\text { heptaphyllum } \\
\text { (Burseraceae) }\end{array}$ & $\alpha$ - and $\beta$-amyrin & $\begin{array}{l}\text { STZ-diabetic mice } \\
\text { with HFD- } \\
\text { induced } \\
\text { hyperlipidemia }\end{array}$ & $\begin{array}{l}\downarrow \text { Blood glucose, } \\
\downarrow \text { Total cholesterol and serum } \\
\text { triglycerides }\end{array}$ & $\begin{array}{l}\text { Santos et al. } \\
\text { (2012) }\end{array}$ \\
\hline- & Oleanolic acid & STZ-diabetic mice & $\begin{array}{l}\downarrow \text { Glucose and triacylglycerides } \\
\text { level } \\
\downarrow \text { Body weight } \\
\downarrow \text { Oxidative stress } \\
\downarrow \text { Gluconeogenesis in the liver } \\
\text { mediated by the Akt/FoxO1 } \\
\text { axis } \\
\uparrow \text { Insulin signal transduction in } \\
\text { hepatocytes } \\
\uparrow \text { Glucose tolerance }\end{array}$ & $\begin{array}{l}\text { Wang et al. } \\
\text { (2011), } \\
\text { Zeng et al. } \\
\text { (2012) }\end{array}$ \\
\hline- & Maslinic acid & $\begin{array}{l}\text { KK-A } \mathrm{A}^{\mathrm{y}} \text { mice } \\
\text { (genetic type } \\
\text { 2-diabetes) }\end{array}$ & $\begin{array}{l}\downarrow \text { Blood glucose level } \\
\downarrow \text { Glycogenolysis via the } \\
\text { inhibition of glycogen } \\
\text { phosphorylase }\end{array}$ & $\begin{array}{l}\text { Liu et al. } \\
\text { (2007) }\end{array}$ \\
\hline- & Asiatic acid & STZ-diabetic mice & $\begin{array}{l}\downarrow \text { Blood glucose level } \\
\downarrow \text { Serum insulin level } \\
\uparrow \beta \text {-cell proliferation } \\
\uparrow \beta \text {-cell pro-survival signaling } \\
\quad \text { (protein kinase B/Akt kinase } \\
\text { activation and Bcl-xL } \\
\text { expression) }\end{array}$ & $\begin{array}{l}\text { Liu et al. } \\
\text { (2010) }\end{array}$ \\
\hline- & Ursolic acid & STZ-diabetic mice & $\begin{array}{l}\downarrow \text { Blood glucose level } \\
\uparrow \text { Plasma and pancreatic insulin } \\
\text { concentrations preservation of } \\
\text { pancreatic } \beta \text {-cells }\end{array}$ & $\begin{array}{l}\text { Jang et al. } \\
\text { (2009) }\end{array}$ \\
\hline- & Astragaloside IV & $\begin{array}{l}\text { HFD-STZ-diabetic } \\
\text { mice }\end{array}$ & $\begin{array}{l}\downarrow \text { Blood glucose level } \\
\downarrow \text { Blood insulin level } \\
\downarrow \text { Hepatic GP and G6Pase } \\
\text { activities }\end{array}$ & $\begin{array}{l}\text { Lv et al. } \\
(2010)\end{array}$ \\
\hline
\end{tabular}


Fig. 7 The scheme of consequences of hyperglycemia in kidney tissue and serum

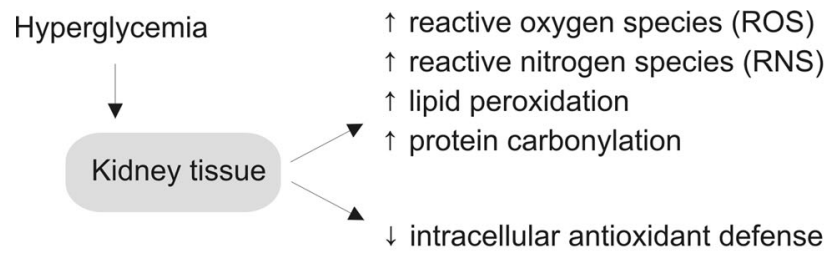

Hyperglycemia

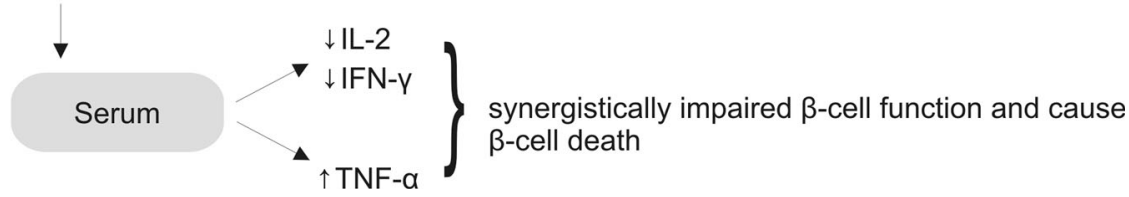

The importance of triterpenes in AGE synthesis and in relieving complications provoked by them

In the etiology of diabetic vascular complications a major role is played by advanced glycation end products (AGEs) produced by non-enzymatic glycation and oxidation of proteins and lipids. AGEs have been implicated in the pathogenesis of diabetic nephropathy, embryopathy, neuropathy or impaired wound healing and independently may predict cardiovascular morbidity and stroke in the diabetic population (Ahmed 2005). Resulting AGEs activate the receptor for advanced glycation end products (RAGE). Activation of RAGE by AGEs causes upregulation of the transcription factor NF- $\kappa$ B and its target genes. Binding of AGEs to RAGE induces a cascade of processes leading to damage of arteries in diabetic patients (Goldin et al. 2006). The role of RAGE has been observed in the development of accelerated atherosclerosis associated with diabetes (Basta et al. 2004).

Some triterpene compounds possess the ability to suppress formation of AGEs and are promising agents in the prevention and treatment of DM complications. Ursolic acid as a strong antioxidant suppressed oxidative stress and ameliorated vascular injury in STZ-induced diabetic rats through inhibition of activation of the RAGE-NADPH oxidase-NF- $\kappa$ B signal transduction pathway (Xiang et al. 2012).

The effect of oleanolic acid and ursolic acid on AGEs production in renal tissue has been examined.
Following treatment of STZ-diabetic mice with these compounds renal aldose reductase activity was suppressed and glyoxalase I activity was enhanced, which contributed to a decrease in renal AGEs formation and an improvement of renal functions (Wang et al. 2010). Oleanolic acid is a strong inhibitor of the formation of glycative products in vitro (Yin and Chan 2007). Also astragalosides and dammarane-type saponins from Astragalus membranaceus (Fabacea) were found to have an impact on the production of AGEs. An in vitro test showed astragaloside $\mathrm{V}$ to have the strongest inhibitory effect of several isolated compounds (Motomura et al. 2009).

Other possibilities of triterpenes use

When HFD-diabetic mice were treated with ursolic acid at a concentration of $0.2 \%$, monocyte chemotactic activity was decreased in correlation with the extent of reduction in atherosclerotic lesion formation. This compound reduced monocyte transmigration and macrophage recruitment. The results suggest that ursolic acid protects monocytes from metabolic stress and inhibits the transformation of healthy monocytes into a hyper-chemotactic phenotype (Ullevig et al. 2011). Ursolic acid administrated to insulin-deficient diabetic mice at a dose of $0.01 \%$, as a food supplement prevented diabetic nephropathy through significant inhibition in $75 \%$ of glomerular hypertrophy and suppression of type IV collagen accumulation in glomeruli. It also suppressed diabetes-induced 
activation of STAT-3, ERK1/2 and JNK pathways, and iNOS overexpression in kidney tissue (Zhou et al. 2010). A neuroprotective effect was observed in hyperglycemic rats treated with maslinic acid (5 or $50 \mathrm{mg} / \mathrm{kg}$ b.w.) after focal cerebral ischemia. A reduction in infarct volumes, improvement of neurological scores and enhancement of the glial glutamate transporter (GLT-1) expression at the protein and mRNA levels have been proven (Guan et al. 2011). A mixture of triterpene acids (with ursolic acid and oleanolic acid as main components) isolated from Cornus officinalis (Cornaceae) fruit suppressed upregulation of mRNA expression of the endothelin system, iNOS and other disorders of this type involved in the development of vascular abnormalities and retinopathy (Su et al. 2007).

\section{Bioavailability and toxicity of triterpenes}

Triterpenes are large molecules and their penetration through cell membranes can be difficult. However, experiments revealed that they permeate into cells, even over the blood-brain barrier, and accumulat in large amounts in the liver. Moreover, chronic intake of triterpene-rich natural products increases their bioavailability and accumulation in circulation and tissues (Yin et al. 2012). It has been observed that the bioavailability of triterpenes can be improved by combining them with cyclodextrins (Cerga et al. 2011).

Natural medication mainly requires repeated intake of high doses of the substance. Therefore, toxicity of maslinic acid has been examined. The results obtained from acute and chronic intake of this compound indicate that it does not exhibit any adverse effects on the variables tested in mice (Sanchez-Gonzalez et al. 2013).

\section{Future of triterpenes as antidiabetic agents}

A review of literature revealed a multidirectional effect of triterpenes. However, plants rich in these compounds are mainly applied in folk medicine, with an exception of the extract from the leaves of Lagerstroemia speciosa, containing corosolic acid as the main component. The extract is available as the preparation Glucosol ${ }^{\mathrm{TM}}$, standardized to contain $1 \%$ corosolic acid (Judy et al. 2003).
Triterpenes can become prototypes for anti-diabetic drugs. Based on the triterpene skeleton derivatives which are more active than their substrates can be synthesized, e.g. oleanolic acid dihydroxy-olide is a stronger $\alpha$-glucosidase inhibitor than the initial substance (Ali et al. 2002) and a derivative obtained in the reaction of maslinic acid with 1,4-dibromobutane is a more potent glycogen phosphorylase inhibitor than maslinic acid itself (Wen et al. 2006).

\section{Conclusion}

The majority of the plants described above containing triterpene compounds are used in various countries in traditional medicine as antidiabetic remedies. Contemporary experiments confirm their activity and, in many cases, explain the mechanisms. Selected triterpenes could become important remedies for curing diabetes mellitus and are promising compounds for the development of new multitarget bioactive drugs. The use of triterpenes as AGEs inhibitors may be a potentially effective strategy to prevent diabetic complications. Their activity has been demonstrated in a number of in vitro studies and on animal models, but continuous clinical research does not exist.

Open Access This article is distributed under the terms of the Creative Commons Attribution License which permits any use, distribution, and reproduction in any medium, provided the original author(s) and the source are credited.

\section{References}

Ahmed N (2005) Advanced glycation endproducts-role in pathology of diabetic complications. Diabetes Res Clin Pract 67:3-21

Alberts P, Engblom L, Edling N, Forsgren M, Klingström G, Larsson C, Rönquist-Nii Y, Öhman B, Abrahmsén L (2002) Selective inhibition of $11 \beta$-hydroxysteroid dehydrogenase type 1 decreases blood glucose concentrations in hyperglycaemic mice. Diabetologia 45:1528-1532

Ali MS, Jahangir M, ul Hussan SS, Choudhary MI (2002) Inhibition of $\alpha$-glucosidase by oleanolic acid and its synthetic derivatives. Phytochemistry 60:295-299

Ali H, Houghton PJ, Soumyanath A (2006) $\alpha$-Amylase inhibitory activity of some Malaysian plants used to treat diabetes; with particular reference to Phyllanthus amarus. J Ethnopharmacol 107:449-455

Ardiles AE, González-Rodríguez Á, Núñez MJ, Perestelo NR, Pardo V, Jiménez IA, Valverde ÁM, Bazzocchi IL (2012) Studies of naturally occurring friedelane triterpenoids as 
insulin sensitizers in the treatment type 2 diabetes mellitus. Phytochemistry 84:116-124

Atanasov AG, Dzyakanchuk AA, Schweizer RAS, Nashev LG, Maurer EM, Odermatt A (2006) Coffee inhibits the reactivation of glucocorticoids by $11 \beta$-hydroxysteroid dehydrogenase type 1: a glucocorticoid connection in the anti-diabetic action of coffee? FEBS Lett 580:4081-4085

Baker DJ, Timmons JA, Greenhaff PL (2005) Glycogen phosphorylase inhibition in type 2 diabetes therapy. A systematic evaluation of metabolic and functional effects in rat skeletal muscle. Diabetes 54:2453-2459

Baltina LA, Flekhter OB, Nigmatullina LR, Boreko EI, Pavlova NI, Nikolaeva SN, Savinova OV, Tolstikov GA (2003) Lupane triterpenes and derivatives with antiviral activity. Bioorg Med Chem Lett 13:3549-3552

Ban CR, Twigg SM (2008) Fibrosis in diabetes complications: pathogenic mechanisms and circulating and urinary markers. Vasc Health Risk Manag 4:575-596

Basta G, Schmidt AM, De Caterina R (2004) Advanced glycation end products and vascular inflammation: implications for accelerated atherosclerosis in diabetes. Cardiovasc Res 63:582-592

Blum A, Favia AD, Maser E (2009) 11 $\beta$-hydroxysteroid dehydrogenase type 1 inhibitors with oleanan and ursan scaffolds. Mol Cell Endocrinol 301:132-136

Brala PM, Hagen RL (1983) Effects of sweetness perception and caloric value of a preload on short term intake. Physiol Behav 30:1-9

Cerga O, Borcan F, Ambrus R, Popovici I (2011) Syntheses of new cyclodextrin complexes with oleanolic and ursolic acids. J Agroaliment Proc Technol 17:405-409

Chen X, Lou G, Meng Z, Huang W (2011) TGR5: a novel target for weight maintenance and glucose metabolism. Exp Diabetes Res. Article ID 853501

Cheng HM, González RG (1986) The effect of high glucose and oxidative stress on lens metabolism, aldose reductase, and senile cataractogenesis. Metabolism 35:10-14

Choi YH, Zhou W, Oh J, Choe S, Kim DW, Lee SH, Na MK (2012) Rhododendric acid A, a new ursane-type PTP1B inhibitor from the endangered plant Rhododendron brachycarpum G. Don. Bioorg Med Chem Lett 22:6116-6119

de Sales PM, Monteiro de Souza P, Alberto Simeoni L, de Oliveira Magalhães P, Silveira D (2012) $\alpha$-Amylase inhibitors: a review of raw material and isolated compounds from plant source. J Pharm Pharmaceut Sci 15:141-183. www.cspsCanada.org

Deutschländera MS, Lall N, Van de Venter M, Hussein AA (2011) Hypoglycemic evaluation of a new triterpene and other compounds isolated from Euclea undulata Thunb. var. myrtina (Ebenaceae) root bark. J Ethnopharmacol 133:1091-1095

Evans JL, Goldfine ID, Maddux BA, Grodsky GM (2002) Oxidative stress and stress-activated signaling pathways: a unifying hypothesis of type 2 diabetes. Endocr Rev 23:599-622

Fröde TS, Medeiros YS (2008) Animal models to test drugs with potential antidiabetic activity. J Ethnopharmacol 115:173-183

Genet C, Strehle A, Schmidt C, Boudjelal G, Lobstein A, Schoonjans K, Souchet M, Auwerx J, Saladin R, Wagner A (2010a) Structure-activity relationship study of betulinic acid, a novel and selective TGR5 agonist, and its synthetic derivatives: potential impact in diabetes. J Med Chem 53:178-190

Genet C, Schmidt C, Strehle A, Schoonjans K, Auwerx J, Saladin R, Wagner A (2010b) Redefining the TGR5 triterpenoid binding pocket at the C-3 position. ChemMedChem 5:1983-1988

Ghosh T, Maity TK, Singh J (2011) Antihyperglycemic activity of bacosine, a triterpene from Bacopa monnieri, in alloxaninduced diabetic rats. Planta Med 77:804-808

Goldin A, Beckman JA, Schmidt AM, Creager MA (2006) Advanced glycation end products sparking the development of diabetic vascular injury. Circulation 114:597-605

Goldstein BJ (2002) Protein-tyrosine phosphatases: emerging targets for therapeutic intervention in type 2 diabetes and related states of insulin resistance. J Clin Endocrinol Metab $87: 2474-2480$

Gowri PM, Tiwari AK, Ali AZ, Rao JM (2007) Inhibition of $\alpha$ glucosidase and amylase by bartogenic acid isolated from Barringtonia racemosa Roxb. seeds. Phytother Res 21:796-799

Guan T, Qian Y, Tang X, Huang M, Huang L, Li Y, Sun H (2011) Maslinic acid, a natural inhibitor of glycogen phosphorylase, reduces cerebral ischemic injury in hyperglycemic rats by GLT-1 up-regulation. J Neurosci Res 89:1829-1839

Harborne JB, Baxter H (1993) Phytochemical dictionary. A handbook of bioactive compounds from plants. Taylor \& Francis, London, pp 728-738

Hou W, Li Y, Zhang Q, Wei X, Peng A, Chen L, Wei Y (2009) Triterpene acids isolated from Lagerstroemia speciosa leaves as $\alpha$-glucosidase inhibitors. Phytother Res 23:614-618

Huang Y-C, Chang W-L, Huang S-F, Lin C-Y, Lin H-C, Chang T-C (2010) Pachymic acid stimulates glucose uptake through enhanced GLUT4 expression and translocation. Eur J Pharmacol 648:39-49

Ishijima S, Takashima T, Ikemura T, Izutani Y (2008) Gymnemic acid interacts with mammalian glycerol-3-phosphate dehydrogenase. Mol Cell Biochem 310:203-208

Jäger S, Trojan H, Kopp T, Laszczyk MN, Scheffler A (2009) Pentacyclic triterpene distribution in various plants-rich sources for a new group of multi-potent plant extracts. Molecules 14:2016-2031

Jang S-M, Yee S-T, Choi J, Choi M-S, Do G-M, Jeon S-M, Yeo J, Kim M-J, Seo K-I, Lee M-K (2009) Ursolic acid enhances the cellular immune system and pancreatic $\beta$-cell function in streptozotocin-induced diabetic mice fed a high-fat diet. Int Immunopharmacol 9:113-119

Jiang B, Yang Y, Jin H, Shang W, Zhou L, Qian L, Chen M (2008) Astragaloside IV attenuates lipolysis and improves insulin resistance induced by TNF $\alpha$ in 3T3-L1 adipocytes. Phytother Res 22:1434-1439

Judy WV, Hari SP, Stogsdill WW, Judy JS, Naguib YMA, Passwater R (2003) Antidiabetic activity of a standardized extract (Glucosol ${ }^{\mathrm{TM}}$ ) from Lagerstroemia speciosa leaves in Type II diabetics. A dose-dependence study. J Ethnopharmacol 87:115-117

Jung SH, Ha YJ, Shim EK, Choi SY, Jin JL, Yun-Choi HS, Lee JR (2007) Insulin-mimetic and insulin-sensitizing 
activities of a pentacyclic triterpenoid insulin receptor activator. Biochem J 403:243-250

Keller AC, Ma J, Kavalier A, He K, Brillantes A-MB, Kennelly EJ (2011) Saponins from the traditional medicinal plant Momordica charantia stimulate insulin secretion in vitro. Phytomedicine 19:32-37

Kuang H-X, Li H-W, Wang Q-H, Yang B-Y, Wang Z-B, Xia Y-G (2011) Triterpenoids from the roots of Sanguisorba tenuifolia var. alba. Molecules 16:4642-4651

Kwon J-H, Chang M-J, Seo H-W, Lee J-H, Min B-S, Na MK, Kim JC, Woo MH, Choi JS, Lee HK, Bae KH (2008) Triterpenoids and a sterol from the stem-bark of Styrax japonica and their protein tyrosine phosphatase 1B inhibitory activities. Phytother Res 22:1303-1306

Lai Y-C, Chen C-K, Tsai S-F, Lee S-S (2012) Triterpenes as $\alpha$ glucosidase inhibitors from Fagus hayatae. Phytochemistry 74:206-211

Laszczyk MN (2009) Pentacyclic triterpenes of the lupane, oleanane and ursane group as tools in cancer therapy. Planta Med 75:1549-1560

Lee M-S, Hwang J-T, Kim S-H, Yoon S, Kim M-S, Yang HJ, Kwon DY (2010) Ginsenoside Rc, an active component of Panax ginseng, stimulates glucose uptake in $\mathrm{C} 2 \mathrm{C} 12$ myotubes through an AMPK-dependent mechanism. J Ethnopharmacol 127:771-776

Li T-H, Hou C-C, Chang CL-T, Yang W-C (2011) Antihyperglycemic properties of crude extract and triterpenes from Poria cocos. Evid base Compl Altern Med. Article ID 128402

Lipson VV, Zamigajlo LL, Petrova ON (2011) Development of $11 \beta$-HSD1 inhibitors for the treatment of metabolic syndrome. Ukr Bioorg Acta 2:3-13

Liu J, Sun H, Duan W, Mu D, Zhang L (2007) Maslinic acid reduces blood glucose in KK-Ay mice. Biol Pharm Bull 30:2075-2078

Liu J, He T, Lu Q, Shang J, Sun H, Zhang L (2010) Asiatic acid preserves beta cell mass and mitigates hyperglycemia in streptozocin-induced diabetic rats. Diabetes Metab Res Rev 26:448-454

Lü H, Chen J, Li WL, Ren BR, Wu JL, Kang HY, Zhang HQ, Adams A, De Kimpe N (2009) Hypoglycemic and hypolipidemic effects of the total triterpene acid fraction from folium Eriobotryae. J Ethnopharmacol 122:486-491

Luo J-G, Liu J, Kong L-Y (2008) New pentacyclic triterpenes from Gypsophila oldhamiana and their biological evaluation as glycogen phosphorylase inhibitors. Chem Biodivers 5:751-757

Lv L, Wu S-Y, Wang G-F, Zhang J-J, Pang J-X, Liu Z-Q, Xu W, Wu S-G, Rao J-J (2010) Effect of astragaloside IV on hepatic glucose-regulating enzymes in diabetic mice induced by a high-fat diet and streptozotocin. Phytother Res 24:219-224

Manna P, Sinha M, Sil PC (2009) Prophylactic role of arjunolic acid in response to streptozotocin mediated diabetic renal injury: activation of polyol pathway and oxidative stress responsive signaling cascades. Chem Biol Interact 181:297-308

Manna P, Ghosh J, Das J, Sil PC (2010) Streptozotocin induced activation of oxidative stress responsive splenic cell signaling pathways: protective role of arjunolic acid. Toxicol Appl Pharmacol 244:114-129
Matsuda H, Murakami T, Jashiro K, Yamahara J, Yoshikawa M (1999) Antidiabetic principles of natural medicines. IV. Aldose reductase and $\alpha$-glucosidase inhibitors from the roots of Salacia oblonga Wall. (Celastraceae): structure of a new friedelane-type triterpene, kotalagenin 16-acetate. Chem Pharm Bull 47:1725-1729

Motomura K, Fujiwara Y, Kiyota N, Tsurushima K, Takeya M, Nohara T, Nagai R, Ikeda T (2009) Astragalosides isolated from the root of Astragalus Radix inhibit the formation of advanced glycation end products. J Agric Food Chem 57:7666-7672

Na MK, Cui L, Min BS, Bae KH, Yoo JK, Kim BY, Oh WK, Ahn JS (2006a) Protein tyrosine phosphatase 1B inhibitory activity of triterpenes isolated from Astilbe koreana. Bioorg Med Chem Lett 16:3273-3276

Na MK, Yang S, He L, Oh H, Kim BS, Oh WK, Kim BY, Ahn JS (2006b) Inhibition of protein tyrosine phosphatase $1 B$ by ursane-type triterpenes isolated from Symplocos paniculata. Planta Med 72:261-263

Na M, Kim BY, Osada H, Ahn JS (2009) Inhibition of protein tyrosine phosphatase $1 \mathrm{~B}$ by lupeol and lupenone isolated from Sorbus commixta. J Enzym Inhib Med Chem 24:1056-1059

Na MK, Thuong PT, Hwang IH, Bae KH, Kim BY, Osada H, Ahn JS (2010) Protein tyrosine phosphatase 1B inhibitory activity of 24-norursane triterpenes isolated from Weigela subsessilis. Phytother Res 24:1716-1719

Oikonomakos NG, Skamnaki VT, Tsitsanou KE, Gavalas NG, Johnson LN (2000) A new allosteric site in glycogen phosphorylase $\mathrm{b}$ as a target for drug interactions structure. Structure 8:575-584

Ono E, Inoue J, Hashidume T, Shimizu M, Sato R (2011) Antiobesity and anti-hyperglycemic effects of the dietary citrus limonoid nomilin in mice fed a high-fat diet. Biochem Biophys Res Commun 410:677-681

Petrash JM (2004) All in the family: aldose reductase and closely related aldo-ketoreductases. Cell Mol Life Sci 61:737-749

Rahimi R, Nikfar S, Larijani B, Abdollahi M (2005) A review on the role of antioxidants in the management of diabetes and its complications. Biomed Pharmacother 59:365-373

Ramachandran S, Prasad NR (2008) Effect of ursolic acid, a triterpenoid antioxidant, on ultraviolet-B radiation-induced cytotoxicity, lipid peroxidation and DNA damage in human lymphocytes. Chem Biol Interact 176:99-107

Ramírez-Espinosa JJ, Rios MY, López-Martínez S, LópezVallejo F, Medina-Franco JL, Paoli P, Camici G, Navarrete-Vázquez G, Ortiz-Andrade R, Estrada-Soto S (2011) Antidiabetic activity of some pentacyclic acid triterpenoids, role of PTP-1B: in vitro, in silico, and in vivo approaches. Eur J Med Chem 46:2243-2251

Rollinger JM, Kratschmar DV, Schuster D, Pfisterer PH, Gumy C, Aubry EM, Brandstöttera S, Stuppner H, Wolber G, Odermatt A (2010) 11 $\beta$-Hydroxysteroid dehydrogenase 1 inhibiting constituents from Eriobotrya japonica revealed by bioactivity-guided isolation and computational approaches. Bioorg Med Chem 18:1507-1515

Sanchez-Gonzalez M, Lozano-Mena G, Juan ME, Garcia-Granados A, Planas JM (2013) Assessment of the safety of maslinic acid, a bioactive compound from Olea europaea L. Mol Nutr Food Res 57:339-346 
Santos FA, Frota JT, Arruda BR, de Melo TS, da Silva AA, Brito GA, Chaves MH, Rao VS (2012) Antihyperglycemic and hypolipidemic effects of $\alpha, \beta$-amyrin, a triterpenoid mixture from Protium heptaphyllum in mice. Lipids Health Dis 11:98

Sasaki T, Li W, Morimura H, Li S, Li Q, Asada Y, Koike K (2011) Chemical constituents from Sambucus adnata and their protein-tyrosine phosphatase 1B inhibitory activities. Chem Pharml Bull 59:1396-1399

Sato M, Tai T, Nunoura Y, Yajima Y, Kawashima S, Tanaka K (2002) Dehydrotrametenolic acid induces preadipocyte differentiation and sensitizes animal models of noninsulindependent diabetes mellitus to insulin. Biol Pharm Bull 25:81-86

Sato H, Genet C, Strehle A, Thomas C, Lobstein A, Wagner A, Mioskowski C, Auwerx J, Saladin R (2007) Anti-hyperglycemic activity of a TGR5 agonist isolated from Olea europaea. Biochem Biophys Res Commun 362:793-798

Seo C, Yim JH, Lee HK, Oh H (2011) PTP1B inhibitory secondary metabolites from the Antarctic lichen Lecidella carpathica. Mycology 2:18-23

Shi L, Zhang W, Zhou Y-Y, Zhang Y-N, Li J-Y, Hu L-H, Li J (2008) Corosolic acid stimulates glucose uptake via enhancing insulin receptor phosphorylation. Eur J Pharmacol 584:21-29

Shih C-C, Lin C-H, Wu J-B (2010) Eriobotrya japonica improves hyperlipidemia and reverses insulin resistance in high-fat-fed mice. Phytother Res 24:1769-1780

Sticher O (2010) Triterpene einschließlich Steroide. In: Hänsel R, Sticher O (eds) Pharmacognosie-phytopharmazie, 9. Auflage. Springer Medizin Verlag, Heidelberg, pp 833-863

Stulnig TM, Waldhäusl W (2004) $11 \beta$-Hydroxysteroid dehydrogenase type 1 in obesity and type 2 diabetes. Diabetologia 47:1-11

Su W, Dai D-Z, Liu H-R, Na T, Dai Y (2007) Upregulated endothelin system in diabetic vascular dysfunction and early retinopathy is reversed by CPU0213 and total triterpene acids from Fructus Corni. Clin Exp Pharmacol Physiol 34:1228-1233

Sudhahar V, Kumar SA, Sudharsan PT, Varalakshmi P (2007) Protective effect of lupeol and its ester on cardiac abnormalities in experimental hypercholesterolemia. Vasc Pharmacol 46:412-418

Suttisri R, Lee I-S, Kinghorn AD (1995) Plant-derived triterpenoid sweetness inhibitors. J Ethnopharmacol 47:9-26

Tahrani AA, Bailey CJ, Del Prato S, Barnett AH (2011) Management of type 2 diabetes: new and future developments in treatment. Lancet 378:182-197

Tan M-J, Ye J-M, Turner N, Hohnen-Behrens C, Ke C-Q, Tang C-P, Chen T, Weiss C-H, Gesing E-R, Rowland A, James DE, Ye Y (2008) Antidiabetic activities of triterpenoids isolated from bitter melon associated with activation of the AMPK pathway. Chem Biol 15:263-273

Thareja S, Aggarwal S, Bhardwaj TR, Kumar M (2012) Protein tyrosine phosphatase 1B inhibitors: a molecular level legitimate approach for the management of diabetes mellitus. Med Res Rev 32:459-517

Uddin G, Rauf A, Al-Othman AM, Collina S, Arfan M, Ali A, Khan I (2012) Pistagremic acid, a glucosidase inhibitor from Pistacia integerrima. Fitoterapia 83:1648-1652
Ullevig SL, Zhao Q, Zamora D, Asmis R (2011) Ursolic acid protects diabetic mice against monocyte dysfunction and accelerated atherosclerosis. Atherosclerosis 219:409-416

Wamil M, Seckl JR (2007) Inhibition of $11 \beta$-hydroxysteroid dehydrogenase type 1 as a promising therapeutic target. Drug Discov Today 12:504-520

Wang Z-H, Hsu C-C, Huang C-N, Yin M-C (2010) Anti-glycative effects of oleanolic acid and ursolic acid in kidney of diabetic mice. Eur J Pharmacol 628:255-260

Wang $\mathrm{X}, \mathrm{Li}$ Y-L, Wu H, Liu J-Z, Hu J-X, Liao N, Peng J, Cao P-P, Liang X, Hai C-X (2011) Antidiabetic effect of oleanolic acid: a promising use of a traditional pharmacological agent. Phytother Res 25:1031-1040

Wen X, Sun H, Liu J, Wu G, Zhang L, Wu X, Ni P (2005) Pentacyclic triterpenes. Part 1: the first examples of naturally occurring pentacyclic triterpenes as a new class of inhibitors of glycogen phosphorylases. Bioorg Med Chem Lett 15:4944-4948

Wen X, Zhang P, Liu J, Zhang L, Wu X, Ni P, Sun H (2006) Pentacyclic triterpenes. Part 2: synthesis and biological evaluation of maslinic acid derivatives as glycogen phosphorylase inhibitors. Bioorg Med Chem Lett 16:722-726

Xiang M, Wang J, Zhang Y, Ling J, Xu X (2012) Attenuation of aortic injury by ursolic acid through RAGE-Nox-NFкB pathway in streptozocin-induced diabetic rats. Arch Pharm Res 35:877-886

Yamaguchi Y, Yamada K, Yoshikawa N, Nakamura K, Haginaka J, Kunitomo M (2006) Corosolic acid prevents oxidative stress, inflammation and hypertension in SHR/ NDmcr-cp rats, a model of metabolic syndrome. Life Sci 79:2474-2479

Yang J, Chen H, Zhang L, Wang Q, Lai M-X (2010) Antidiabetic effect of standardized extract of Potentilla discolor Bunge and identification of its active components. Drug Dev Res 71:127-132

Yasukawa K, Akihisa T, Oinuma H, Kasahara Y, Kimura Y, Yamanouchi S, Kumaki K, Tamura T, Takido M (1996) Inhibitory effect of di- and trihydroxy triterpenes from the flowers of Compositae on 12-O-tetradecanoylphorbol-13acetate-induced inflammation in mice. Biol Pharm Bull 19:1329-1331

Yin MC, Chan KC (2007) Nonenzymatic antioxidative and antiglycative effects of oleanolic acid and ursolic acid. J Agric Food Chem 55:7177-7181

Yin M-C, Lin M-C, Mong M-C, Lin C-Y (2012) Bioavailability, distribution, and antioxidative effects of selected triterpenes in mice. J Agric Food Chem 60:7697-7701

Zeng X-Y, Wang Y-P, Cantley J, Iseli TJ, Molero JC, Hegarty BD, Kraegen EW, Ye Y, Ye M (2012) Oleanolic acid reduces hyperglycemia beyond treatment period with Akt/ FoxO1-induced suppression of hepatic gluconeogenesis in type-2 diabetic mice. PLoS One 7:1-12

Zhang W, Hong D, Zhou Y, Zhang Y, Shen Q, Li J-Y, Hu L-H, LI J (2006) Ursolic acid and its derivative inhibit protein tyrosine phosphatase $1 \mathrm{~B}$, enhancing insulin receptor phosphorylation and stimulating glucose uptake. Biochim Biophys Acta 1760:1505-1512 
Zhang XS, Bi X-L, Bi X-L, Wan-Xiao, Cao J-Q, Xia X-C, Diao Y-P, Zhao Y-Q (2013) Protein tyrosine phosphatase 1B inhibitory effect by dammarane-type triterpenes from hydrolyzate of total Gynostemma pentaphyllum saponins. Bioorg Med Chem Lett 23:297-300
Zhou Y, Li J-S, Zhang X, Wu Y-J, Huang K, Zheng L (2010) Ursolic acid inhibits early lesions of diabetic nephropathy. Int J Mol Med 26:565-570 